\title{
Cultural Heritage of the egyptian form: An Approach to the DEsign tradition of HangIng textILES
}

\author{
By \\ Dalia Kamal Ibrahim Basyouni \\ Dr. Pammi Sinha \\ Lecturer in Department of Printing \\ Associate Professor Fashion \\ Textiles, Dyeing and Finishing \\ Management \\ Faculty of Applied Arts, \\ Programme Leader MA Fashion \\ Damietta University \\ Enterprise and Society \\ School of Design, University of Leeds \\ United Kingdom- England
}

\section{Research Gournal Specific Fducation}

Faculty of Specific Education

gYansoura University

ISSUE NO. 48, OCTOBER. 2017

مجلة بحوث التربية النوعية - جامعة المنصورة

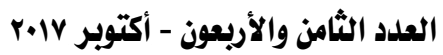




\section{Cultural Heritage of the egytian form: AN Approach to the Design tradition of HangIng TeXtIles}

\section{Dalia Kamal Ibrahim Basyouni* Dr. Pammi Sinha"}

\section{Abstract}

This article considered the development of hanging textile design in Egypt. The aim of the paper is to outline the Egyptian traditions and beliefs in design that characterize Egyptian hanging textile design authenticity. The focus and scope on the development of design thinking within Egyptian cultural heritage required a reflexive approach on the anthropological practice of hanging textile design and its attendant socio-cultural relations which constituted the design strategies of hanging textiles in Egyptian history. To achieve a better understanding of how have designs of hanging textiles in Egypt developed through the ages and the hanging design traditions of each age, the article weaved the hangings textile design traditions and three major historical periods of Egypt through examined the culture, art and design of hanging textiles in Pharaonic Egypt, Coptic era and Islamic Egypt. Besides, the influence of weaving technology on Coptic style. It also focused on the design traditions throughout the Egyptian history as the structural mechanism interwoven with relationship between culture heritage and textile designer. It defined as the ideological applications and can be interpreted into cultural transmission. The article shed light on the cultural significance of hanging textiles in Egypt.

From our review of three eras in Egyptian history, hanging textile design in Egypt has significant values and practices throughout history, the customs associated with its production reinforce the sense of identity and build up links with the Egyptian historical context.

* Lecturer in Department of Printing Textiles, Dyeing and Finishing Faculty of Applied * Arts, Damietta University

Associate Professor Fashion Management Programme Leader MA Fashion Enterprise and Society School of Design, University of Leeds United Kingdom- England 
Authenticity of the Egyptian hanging textiles through design traditions and culture regard as a matter of style, it is a way, a method, a mode of existence- it is a matter of how Egyptian hanging textiles were designed. Culture systems have a profoundly important effect on the ontological status of an art work (modes of being of the art object). Thus, hanging textiles in this case embodies some mode of being and cover the style of a specific period as a result of Egyptian society's ideology. It is a kind of acceptance of the social circumstances during this time.

\section{Introduction}

Textiles held a special place in Egypt from the late Antiquity period (popularly known as the Coptic period) as art in a domestic setting, providing a "medium for ornamentation and image", and large wall hangings and curtains occupied important places in the houses of the rich and official buildings ${ }^{1}$. This article will consider the development of hanging textile design in Egypt. The aim of the paper is to outline the Egyptian traditions and beliefs in design that characterize Egyptian hanging textile design authenticity through considering the following:

- How have designs of hanging textiles in Egypt developed through the ages?

- What are the hanging design traditions of each age?

- How is culture involved in the practice of hanging textiles through which the design tradition is constructed?

Implicit to this approach is a critical perspective on the Egyptian design thinking about hangings design and provides a context by which to explore inclusion of ideologies within the design process. The focus and scope on the development of design thinking within Egyptian cultural heritage required a reflexive approach on the anthropological practice of hanging textiles design and its attendant socio-cultural relations which constituted the design strategies of hanging textiles in Egyptian history. This approach, which Anna (2009) refers to as "cognitive anthropology"2, reviews Egyptian artistic styles filled with decorative vocabularies that prompted hanging textiles on the one hand and design traditions on the 
other. They offer unique and design perspective from which to consider how ideological practices are continued across generations and informed the artistic features of each stage, thus the "authenticity" of Egyptian hanging textiles is called into question.

Nevertheless, the aim is not to consider the ideological phenomena per se, but rather the traditions and beliefs in design that create an Egyptian category in hanging textiles design which might tell us about the nature of learning and knowledge for future development and form a foundation from which contemporary designers can broaden their ideas. ${ }^{3}$ This is reinforced by Micheli, and Gemser (2016) when they stated that "the adherence to a design tradition can strength and effect on the relationship between design innovativeness and performance". ${ }^{4}$ To achieve a better understanding of how have designs of hanging textiles in Egypt developed through the ages and the hanging design traditions of each age, the following section weaves the hangings textiles design traditions and three major historical periods of Egypt which is still of relevance to contemporary Egyptian woven textiles design for hangings. ${ }^{5}$

\section{Culture, art and design of hanging textiles in Pharaonic Egypt:}

The ancient Egyptians knew textiles and excelled in patterning them, Barber (1982) noted that (temporally later) Coptic hanging tapestries were woven using a weaving method known since the time of pharaohs ${ }^{6}$. The textiles were made for a variety of purposes such as garments, sails, covers for canopies and cushions. However, trying to determine the beginning of textiles using by ancient Egyptians in hangings or in decoration is difficult because of the lack of physical evidence or representations in mural paintings and reliefs on tomb walls (which give us intimate pictures of the life and customs of the Egyptians ${ }^{7}$ ). This may be due to Pharaonic Egypt's preoccupation with preparations for the royal tomb and the construction and decoration of temples, the embellishment of royal dwellings interior walls with paintings executed in a tempera technique or with painted carved relief. $^{8}$ 
Pharaonic Egyptian art was functional, funerary art served exclusively the requirements of the idea of eternity. Their beliefs in immortality of gods directed their thinking to build royal tombs and temples that functioned as both the residence of the gods who dwelt within its enclosure and also provided a symbolic model of the universe. ${ }^{9}$ Perhaps the reason why textiles were not used in hanging as they would deteriorate more quickly compared to the stones and this lack of longevity contradicted the idea of eternity. Moreover, the creed imposed them prohibition of certain materials such as wool as they considered it unclean ${ }^{10}$ which may also dissuaded further the use of textiles for decoration purposes, rather the evidence seems to indicate the use of matting or leather instead of textiles in hangings and decoration with geometrical designs brightly colored. ${ }^{11}$

The ancient Egyptian artist focused on recording reality and life events for a panoramic approach to the representation of the pharaoh, thus serving creed and religious thought. Pharaonic Egyptian art was not concerned with presenting an individual impression, but rather with what was regarded as eternal verities. This contradicts more modern purposes of art where new artistic visions are sought with inspirations from the artist's subjectivity. Designs of Pharanoic Egypt were immutable, established as an institution of the Egyptian state; the fundamental principles for design and uses of shapes remained the same even when the High Priest changed from a period to another. What was important was conforming to a sanctified creative mode and not the expression of a personal view of reality.

Often, the High Priest was responsible for the designs, drawings of the temple walls and execution of Egyptian artworks (he bore the title of chief designer) ${ }^{12}$ and sometimes many aspects of artistic expression were exclusive to the king. ${ }^{13}$ Then, after that came the role of the "painter" who executed the design by drawing the outline designs on the walls "scribedraftsmen", ${ }^{14}$ they were professional craftsmen, with high technical skills, who usually worked as members of teams under the guidance of the chief designers. Therefore, the drawings, figures and designs during the Pharaonic age appear to be of similar style because of the practice of portraying the artistic vision imposed by one person. Consequently, there is a design 
tradition due to anthropological practice of the Egyptian artist. Thus, the authenticity of this art had emerged and has independent entity.

\section{Culture, art and design of hanging textiles in Coptic era:}

Copts are descendants of ancient Egyptians and one of the earliest Christian groups outside of the Holy Land. The Coptic Church is believed to date back to about 50AD; the apostle Mark the Evangelist is recorded to have gone to Alexandria between 43-44AD by the second century historian Eusibius. ${ }^{15}$ Martyred in Alexandria, Mark is regarded as the first pope of the Coptic Church. Copts appeared in Egypt after Greeks had settled in several Egyptian cities in the late of Pharaonic era, conquering the land under the rule of "Alexander the Great", 16 followed by Roman occupation. Accordingly, Egypt was influenced by Greek and Roman culture and art. During this time, Christianity appeared and many Egyptians embraced it. ${ }^{17}$

Coptic textiles have been considered an extension of Pharaonic textiles, as Copts decorated their textiles in the form of garments and furnishings such as hangings, covers and pillows with art and motifs of Egyptian origin ${ }^{18}$ but sometimes influenced by foreign artistic elements of the countries that had raided and occupied Egypt. Patterned Coptic textiles show the influences of Pharaonic culture followed by Greek, Roman and Byzantine idiom. ${ }^{19}$ Hanging textiles of the Coptic period discovered in the tombs of Saqqara, Akhmim and other places in a good condition because they were preserved in the dry soil ${ }^{20}$ of the Egyptian burial grounds as grave goods. Copts were proficient in hanging textiles; they produced many of them in a weaving technique "Tapestry" as well as "Embroidery". ${ }^{21}$ Almost all the hangings found were woven in tapestry decorated with dyed wool on a linen ground designed for warmth and decorative function. ${ }^{22}$ For printed hanging textiles, Rutschowscaya (1990) noted ${ }^{23}$ that there were examples of printed hangings on linen using brightly coloured natural dyes. This shows that the Copts were aware of techniques of printing textiles as a mean of decorating fabrics and this is confirmed by discoveries of printers' blocks, materials ${ }^{24}$ and hangings in resist printing technique. ${ }^{25}$ 
Notably, Coptic art flourished around the period of the persecutions of Christians during the Roman rule in Egypt. ${ }^{26}$ Prevented from expressing emotions and affiliation to Christianity, textiles became a method of communicating as well as adorning and providing warmth for the Copts. Hanging textiles were the best hidden way for expression when comparing it with any other forms of art such as wall paintings and sculpture; as they were easy to remove from the wall, fold and hide in case of a sense of danger. "It was a way of asserting Egyptian identity against the oppressive Byzantium and Orthodox Patriarch rule" ${ }^{27}$ Copts mastered the art of textiles and possessed high skill as weavers and produced many artisans. ${ }^{28}$ Since Egypt was not subject to the rule of Copt, so the Coptic art was generally a popular art (produced everywhere). Therefore, the Coptic textile industry centers were not confined only to big cities such as Alexandria and Akhmim where great guilds and organizations of professional weavers were found, but home industries were carried on, and the fellah, or Egyptian peasants, wove the textiles for their own use, thence hanging textiles were locally designed and woven. All textiles of the Coptic era were woven by professional artist-weavers and peasants, ${ }^{29}$ who had played an important role in the creation and establishment the features of Coptic art. They were organized in corporations with a president (master of the looms) who was in a direct contact with government officials, and they were paid according to the quantity and quality of productions. ${ }^{30}$ The Christian weaver depended on several sources of inspiration for tapestry decorations, from pattern book, other textiles, paintings and mosaics. ${ }^{31}$

Textiles during the Coptic era were adorned by various motifs and designs appropriate for the purpose of use whether "garments, coverings or hangings". The Coptic weaver frequently used biblical scenes and Christian figures $^{32}$ to embellish textiles to such an extent that it appeared that people were carrying the Bible on their clothing. Davis $(2005)^{33}$ reasoned that this was to convey a sense of divine protection from diseases and sickness, explaining the use of such textiles in burial setting.

Coptic artists created woven tapestry textiles used as coverings and hanging on walls. The surface ground of the textiles were filled using fruits 
and flowers and sometimes were surrounded by borders or stripes consisting of a band of plant and geometrical patterns. ${ }^{34}$ It is clear in the motifs of that period the identity and character of the Coptic art which bearing mystical features $^{35}$ that characterized the Coptic people and manifested in their artworks either on textiles or paintings.

Overall, the Coptic art, especially hanging textiles have many figurative and representational scenes by various forms of weaving, especially in tapestry. The character of motifs in this era were based on creed and Christian representation, ${ }^{36}$ therefore most of their themes became religious. Also, Christian symbolism played a major role in their hanging textiles such as quails, fish, grapes, animals ${ }^{37}$ and the Cross which appeared in several forms as an attempt from the Coptic weaver to made it as inconspicuous as possible fearing of persecution. These Christian symbols figures were used with oriental design and floral ornament in a multicolored scheme ${ }^{38}$; they are considered artistic elements which have both religious character and decorative qualities.

\section{The influence of weaving technology on Coptic style:}

Weaving technology had an important role in forming the aesthetic expression of Coptic textiles as the weaver developed several weaving techniques on the loom such as "tapestry" to produce a variety of decorative effects, some of which imitated other fields of art such as painting or mosaics. ${ }^{39}$ The weaver then used this technique to distort the figures and convert them into ornamental forms. Additionally, the Coptic weaver solved artistic problems such as the flat pattern whereby contours were woven into the fabric around the figures to give them additional dimension where all the shapes were outlined by white or black borders and sometimes were defined by coloured woven lines. Later, these lines that subdivided or outlined the shape became the main features of the Coptic style. ${ }^{40}$

The Coptic weaver, therefore, created in the light of what the weaving technology, materials and tools enabled and individual expression, unlike the Pharaonic artist. Thus, the style of the Coptic era was shaped by a relationship between the craftsperson's expression, their techniques and 
technology. This concept is a glimpse of the democratic interventions of technology in the modern strategy of textile design, where the chief goal of any textile designer is to discover an independent authentic style to express new ideas of textile production in an untraditional way. This cannot be achieved without relying on techniques; one cannot separate the designer from materials and technology because they are key to a designer's creativity, their artistic approach and style.

\section{Culture, art and design of hanging textiles in Islamic Egypt:}

Islamic era in Egypt began during the Arab conquest of Egypt in 640 $\mathrm{AD}$ when the fortress of Babylon (old Cairo) was captured by the Arabs in the seventh century when Cairo was one of the greatest centers of textiles production. ${ }^{41}$ At that time, Egyptian textiles were famous, in a stage of progress and maturity, but Arabs influenced Egyptian textiles industry and its decorations opening a new field of ornamental beauty. ${ }^{42}$ Arabs imposed their censorship on the textiles industry in the Islamic era as the domestic factories were not free to weave as much as they want. They were provided with raw materials from the government and fabrics were woven under the license of the government; ${ }^{43}$ official weaving factories were managed by the government itself. Textiles were produced with all its functional purposes for garments, domestic furnishings, carpets, hangings, curtains and cushion covers, as well as palace uses, diplomatic gifts, ${ }^{44}$ and to drape the Kaaba at Mecca (sacred site in Saudi Arabia for worship).

Froom (2013) ${ }^{45}$ noted that textiles were an important source of income and a vital component of Islamic Egypt economy, where silk tapestry of unbelievable fineness gold and wool textiles were in high quality production for export to Europe. ${ }^{46}$ Silk, for decorative purposes prevailed and spread during the Islamic period, ${ }^{47}$ presumably as men were prohibited from wearing it in Islam, and probably the reason that silk was used in other purposes rather than clothing. Under the early Arabs decorative themes dominant in the Coptic era remained in use for the decoration of various textiles including woven hangings; but the textiles which had a Christian character were limited to the Christian Egyptians who did not embrace 
Islam. Textiles attributed to the early Islamic period designed with Christian subjects treated anti-naturalistically, where Christian patterns were accompanied with Arabic writings in a complete artistic fusion ${ }^{48}$ were influenced by the new religion (Islam), its writings and inscriptions.

During the Islamic period, textiles designs changed where a variety of decorative styles and techniques were developed to embellish the surfaces of textiles. Geometrical patterns ${ }^{49}$ were more commonly used by the Islamic artist who reduced the figurative art (representational art) due to religious considerations. ${ }^{50}$ In line with non-figurative designs, designs also took on transformation of vegetal forms to create "arabesque" which is based on undulating stalks and split leaves or palmettes governed by geometry ${ }^{51}$ and Calligraphy "Kufic and thuluth" as a mode of decoration for textiles hangings combined with various kinds of decorations. ${ }^{52}$ Here, the letters were ornate and terminated in an oblique angle, became bifurcated, generated half-palmettes and began blossoming out. Baer "1998" ${ }^{53}$ referred to this foliated ends as "floral embellishments of the letters". Designers who might be professional painters or miniaturist created the designs for textiles, these designs might be repeated or adapted by the weavers without further recourse to a designer. The weavers were highly trained executants, translated the design into knotted pile ${ }^{54}$ to construct the pattern depending on their skill of eye and hand. Technology again played its part in developing the authenticity of the finished products - weaving techniques enhanced the appearance of silk textiles where a technical refinement established loosely textured patterns against a smoother background and new techniques of velvet making, chiefly for large covers and hangings. ${ }^{55}$

\section{Design traditions throughout the Egyptian history:}

What should be considered in the Egyptian society are the questions of various art practices arising from cultural diversity throughout Egyptian history and how the textile designer formulates the socio-culture circumstances into artworks bearing the Egyptian identity, to work towards further development and better future. Jeong $(2016)^{56}$ stated that "identity is a socially organized cultural construction, which changes historically". 
From our interrogation of the Egyptian design traditions, we can conclude that they were all based on religious origin and belief, whether in the ancient Egyptian art which serves the eternity creed of gods and kings, in Coptic textiles patterns stemming from their faith in Christ using biblical themes and symbols to refer to concepts in Christianity or Islamic art which tried to create new art forms consistent with the principles of Islamic religion where absence of figures is the characteristic feature of Islamic art. This of course has a major impact on the culture of Egyptian society in each period and consequently on its anthropological practices.

We have presented the pattern/form creations within the Egyptian textile design tradition through three eras of cultural development to account for the textile hanging design developments in relation to Egyptian society's ideologies. We have taken an anthropological approach to examine how Egyptian authenticity has been produced through systems of design practices of hanging textiles which is clearly defined in the context of modern influences. This may be considered as conservative philosophy as opposed to modernism. ${ }^{57}$ A society, bound by sociological traditions that provided the shared understandings among its individuals, can build up their culture which in turn is a crucial factor that enables them to build up their design tradition; ideologies are a crucial factor in developing design traditions, ${ }^{58}$ identity and authenticity of their products. Micheli and Gemser $(2016)^{59}$ referred to the national design tradition as a design style which creates a recognizable product identity formed by a unique set of design features that characterize products from a geographic area over time. Lascar $(2014)^{60}$ noted that design traditions are the objects which create bonds between individuals of a certain group and their culture, consequently cultural heritage refers to "a set of tangible and intangible assets" used by people to express themselves; through this process "design join several areas such as anthropology, history and sociology". In this way, design traditions consider the source to engage into traditional way of thinking and habitual ways of hanging textile design in Egypt. It is the ontological status of hanging textiles as being in accordance with the region's traditions and had affinities with society's own tradition. ${ }^{61}$ Therefore, this paper has 
emphasized on reflection-on-action of the Egyptian textiles designers, their thinking and ideologies considerations in the practice of hanging textiles design or in other words it elucidate the socio-cultural contexts into a web of Egyptian design practices weaved by tradition; ${ }^{62}$ because design tradition interprets the cognitively-built relation of an object that includes features (beliefs/ actions/ situations/ events) in contact with the surroundings into a coherent unit.

Design tradition is the structural mechanism ${ }^{63}$ interwoven with relationship between culture heritage and textile designer. The cultural identity of a particular place at a specific time is incarnated into forms and patterns defined by certain rules and standards ${ }^{64}$ that constitutes the concrete design traditions and advocates a particular form of design practice for achieving it. Let us draw attention to what has been argued by "Noyes" $(2009)^{65}$ that tradition is the ideological applications and can be interpreted into cultural transmission. For Micheli and Gemser $(2016)^{66}$, the consistency with tradition supports product authenticity, it is the framework in which designers can develop innovative designs which possess the identity of a geographical area. MacNeil and Mak (2007) ${ }^{67}$ referred to design traditions as "traditional culture resources". Therefore, the design traditions of hanging textiles may be considered as the result of ideologies through time which directed the Egyptian textile designer to this distinctive form in design.

\section{The cultural significance of hanging textiles in Egypt:}

We are interested as textile designers to study hanging textiles from their cultural and social contexts and not merely as an art objects as recommended by Biggs (2009). ${ }^{68}$ From our review of three eras in Egyptian history, hanging textile design in Egypt has significant values and practices throughout history, the customs associated with its production reinforce the sense of identity and build up links with the Egyptian historical context. Hanging textiles has many forms; it could be curtains, wall coverings, decorative barriers...etc. The reason to focus specifically on hanging textiles, their design thinking and patterning techniques is because they had 
sharp and crucial transformations that distinguished each period in the Egyptian history because of critical circumstances. They were considered essential products in the Egyptian society, as heat insulator ${ }^{69}$ as well as decorative purposes. It is an important cultural artefact contributed in the construction of Egyptian artistic style throughout its history especially when the Copts resorted to it as the best hidden art form to express their beliefs and emotions; this period has been considered the real start of the Egyptian hanging textiles. ${ }^{70}$ This way, hanging textiles from its beginning are a rich field of design thinking and development along the Egyptian history. As an Egyptian textile designer trying to maintain authenticity in her designs, it is important to understand Egyptian design traditions, how and why these traditions transformed, changed and were shaped from one period to another along the Egyptian history.

\section{Authenticity of the Egyptian hanging textiles through design traditions and culture:}

Broadly speaking, authenticity has many aspects; it can refer to the idea of genuine and false ${ }^{71}$, to be yourself or to follow your conscience. In this research, we have understood authenticity as the idea of being original or the idea of expressing what you are through some things ${ }^{72}$. MacNeil and Mak $(2007)^{73}$ argued that authenticity has been constructed in traditional environments and it can be understood as a social construction to achieve a certain aim. They argued that authenticity of a work of art constitutes from the cumulative tradition that runs from its conception to its present state. Liedtka $(2008)^{74}$ concurred with this when noting that the notion of authenticity is rooted in known traditions constructed through social context. In this work we tried to examine authenticity through the relations between Egyptian hanging textiles and its socio-culture conditions of production and circulation, mediated through the work of ideology. ${ }^{75}$

Furthermore, "The Dictionary of Critical Theory, 2010", ${ }^{76}$ argues that authenticity may be treated as a project; something one aspires to or works towards, that is, that authenticity is not immutable. The authenticity of Egyptian hanging textiles should be considered in terms of both what the 
design is and why they were designed in this form. Authenticity has a unique internal essence as a product of network of inalienable relationships between the Egyptian textile designer, form of hanging textiles and place as well as the production of identities and values. Thus, elements of authenticity are depicted in material, methods of construction and pattern ${ }^{77}$ which are controlled by actions of textile designer represented in design process. Authenticity is also in relation to human character, ${ }^{78}$ on this account, authenticity of Egyptian hanging textiles is in relation to designer, their design thinking throughout history, that in turn focus on underlying "origin" of anthropological practices of hanging textiles design. For, on this definition, authenticity regard as a matter of style, it is a way, a method, a mode of existence- it is a matter of how Egyptian hanging textiles were designed. This can be summed up in Heidegger's conception of authenticity as a response to an existential crisis; ${ }^{79}$ therefore we can situate the new art forms which were innovated by the Coptic and Islamic textile designer due to religious considerations as a kind of response to existential circumstances. In this broader sense, authenticity of Egyptian hanging textiles is the ability to forge ahead with some course of action that makes sense in terms of existence circumstances. Artistically designed Egyptian hanging textiles frequently achieved their authenticity in terms of formal qualities, regional distinctive styles of each period along the Egyptian history and the differences in execution of motifs in which all are controlled by the relationship between the Egyptian designer and society's ideologies. We can interpret this crucial link into direct engagement of the designer with the material culture of a particular place and time ${ }^{80}$ responsive to a range of circumstances and respectful of certain standards.

Authenticity is a term uses as a synonym for artistic production that has properties appropriate to the cultural context through which it is produced, ${ }^{81}$ or to be precise, it is a product of "culture", 82 and culture is a product of "actions" (behavior and beliefs of a group of people constituting the distinctive achievement in their productions, lifestyle and practices); the essential core of culture consists of traditional patterns, ideas and their attached values. ${ }^{83}$ Culture systems have a profoundly important effect on the 
ontological status of an art work (modes of being of the art object). ${ }^{84}$ Thus, hanging textiles in this case embodies some mode of being and cover the style of a specific period as a result of Egyptian society's ideology. It is a kind of acceptance of the social circumstances during this time. ${ }^{85}$ For Jones $(2010)^{86}$, "authenticity is the quality that is culturally constructed, inherent in the material fabric, form and function of artifacts". This support the significant part of authenticity in culture practices, it resembles Heidegger's account of one's being by "what one makes of the possibilities one finds in one's historical culture". ${ }^{87}$ In this sense, hanging textiles embedded in a context of concrete relations (historical culture relations) that define their identity. Egyptian hanging textiles is therefore an entity that can be held or achieved through Egyptian ideologies which in turn leads to the symbolic, expressive and stylistic properties of hanging textiles along the Egyptian history.

Artistic authenticity of a product may be displayed in two forms closely bound together: conceptual forms (e.g. originality, exclusivity) and incarnate forms (e.g. creative process, final designs); ${ }^{88}$ through close scrutiny to these two forms of authenticity, it is quite obvious that they are embedded in the production of specific art forms of Egyptian hanging textiles. The relationship between them gives moral force to the socialcultural-historical relations which contribute to the building of originality of Egyptian designs that incarnated in the form of hanging textiles. Originality refers to the circumstances of creation ${ }^{89}$ of such art forms or refinement of existing rules as pointed by Crowther (1991), ${ }^{90}$ this reified in the Coptic textile designer who resorted to alter religious symbols such as the Cross and made it as inconspicuous as possible fearing of persecution. Darby $(2012)^{91}$ alluded to the relations of multifarious influences to individual's creativity and reside authenticity in a unique design. She discussed that the designer rarely conceives of a product in isolation of ideologies and the creation of new art forms resultant of socio-cultural contexts as influences contribute to the culture authenticity of an artwork as being a product of a specific environment at a precise time. 
On this basis, creation is to bring a product into existence which emphasis on the value of a design arising from society's ideologies (birth of designs) ${ }^{92}$ and carries the history and development during that time. Consequently, hanging textiles are an expression of the cultural anthropology across the Egyptian history, this is the point that the Egyptian form qualitatively varies from one period to another as the anthropological practices of a design always changeable depending on socio-cultural circumstances, and thereby the goals and structures of authenticity differ from one age to another and from one field to the next. ${ }^{93}$ Authenticity is therefore not a static state of being but a constant process of creativity, this explains why Fine $(2003)^{94}$ referred to authenticity as the "the recognition of difference". As a consequence, authenticity of Egyptian hanging textiles is the link between the final product (hanging textiles) and the creative process which is steered by social context of human groups.

\section{Conclusion:}

In this article, we have tried to trace the design tradition metamorphoses in the Egyptian history through recourse to beginnings of hanging textiles, the design thinking in their production and the reasons that led to their emergence as an art objects interpret the transformation of design thinking innovated by the Egyptian textile designer. The chronological span of the study is rather wider as it starts with the ancient Egyptian art as an oldest civilization, then Coptic art and followed by Islamic design traditions as crucial art movements in Egyptian design history. This article considered the validity of society's ideologies in shaping of design traditions which affect both design history and practice. Egyptian ideologies originating from interaction of social and cultural factors were the guiding principles for design tradition construction and contribute to the issue of authenticity and identity, thus hanging textile design becomes the icon of society's tradition. Categorizing hanging textile design traditions triggers further thoughts on the dynamic and complex flow of socialcultural-historical contexts in the anthropological practices of design (practices of tradition) which enrich the design history, contributes in further development of design activities as stated by Ögut (2009) that "It opens up 
new possibilities for future significations and life forms",95 and generates stereotypical conception $^{96}$ of hanging textile design in different sociocultural settings. The aim of this paper is an attempt to emphasize that every object (we focused on hanging textiles) defines the social, cultural, historical and geographical context it belongs to and being constructed and innovates upon. In this case hanging textile design becomes part of the culture in which it is born and come from; consequently it being a part of tradition which bears a sense of authenticity and identity.

\section{Notes}

1- A. M. Stauffer, Textiles of Late Antiquity, Metropolitan Museum of Art, New York, 1995.

2- A. O. Portisch, "Techniques as a window onto learning: Kazakh women's domestic textile production in Western Mongolia," Journal of Material Culture, vol. 14, no. 4, 2009, pp. 471-493.

3- N. U. Maruyama, T.-H. Yen and A. Stronza, 'Perception of Authenticity of Tourist Art among Native American Artists in Santa Fe, New Mexico', International Journal of Tourism Research, vol. 10, no. 5, 2008, pp. 453-466, p. 461.

4- P. Micheli and G. Gemser, 'Signaling Strategies for Innovative Design: A study on Design Tradition and Expert Attention', The Journal of Product Innovation Management, vol. 33, no. 5, 2016, pp. 613-627, p. 617.

5- M. M. Amer, "Cotemporary view for upholstery and curtain jacquard fabrics with woven hanging design", Textile Journal, pp80-89

6- E. J. W. Barber, 'New Kingdom Egyptian Textiles: Embroidery vs. Weaving', American Journal of Archaeology., vol. 86, no. 3, 1982, p. 443.

7- E. Riefstahl, Patterned Textiles in Pharaonic Egypt, Brooklyn Institute of Arts and sciences, New York, 1944, p.1.

8- T. G. James, Egyptian Painting and Drawing in the British Museum, British Museum Publications Limited, London,1985, p.6.

9- R. H. Wilkinson, Symbol and Magic in Egyptian Art, Thames and Hudson Ltd, London, 1994, p.27.

10- Riefstahl, op. cit., p.29.

11- Ibid., pp.16-18. 
12- C. Aldred, Egyptian Art in the Days of the Pharaohs, 3100-320 BC, Thames and Hudson, London, 1980, p. 12.

13- C. Riggs, 'The Art of Ancient Egypt', African Arts, vol. 35, no. 2, 2002, pp. $11-88$, p.88.

14- W. Davis, 'Scale and Pictoriality in Ancient Egyptian Painting and Sculpture', Art History, vol. 38, no. 2, 2015, pp. 268-285, p. 278.

15- J. E. Gillespie. The Egyptian Copts and Their Music. Pdf. Retrieved from the Library of Congress, https://www.loc.gov/item/ihas.200155643/, p.4 .

16- G. Gabra, Coptic Monasteries: Egypt's monastic art and architecture, American University in Cairo Press, Cairo, 2002, p. 10.

17- B. Museum, Late Egyptian and Coptic art: an introduction to the collections in the Brooklyn Museum, New York: Brooklyn Institute of Arts and Sciences, 1943, p. 10.

18- M. S. Dimand, 'Coptic Textiles: Recent Accessions', The Metropolitan Museum of Art Bulletin., vol. 21, no. 4, , 1926, pp. 102-105, p. 105.

19- N. A. Hoskins, 'Coptic Textiles. An online exhibition of the California Academy of Sciences', Museum Anthropology, vol. 30, no. 1, 2007, pp. 48-49, p. 48.

20- M. Villard, 'Coptic textiles from the Kelekian collection', Parnassus, vol. 3, no. 4, 1931, pp. 31-32, p. 31.

21- L. Kybalová, Coptic Textiles, London: Hamlyn, 1967, p. 39.

22- J. D. Cooney, 'Problems of Coptic Art', in Coptic Egypt, T. B. M. Press, Ed., Brooklyn Institute of Arts and Sciences, New York, 1944, pp. 35-41, p. 38.

23- M.-H. Rutschowscaya, Coptic Fabrics, Adam Biro, Paris, 1990, p. 28.

24- Kybalová, op. cit., p. 39.

25- Rutschowscaya, op. cit., p. 28.

26- Gabra, op. cit., p. 12.

27- D. Thompson, “"Miniaturization” as a Design Principle in Late Coptic Textiles of the Islamic Period: Observations on the classification of Coptic textiles', Journal of the American Research Center, vol. 22, 1985, pp. 55-71, p. 61.

28- G. U., 'Coptic Textiles', The Bulletin of the Cleveland and Museum of Art, vol. 13, no. 9, 1926, pp. 193-196, p. 194.

29- Dimand (1926), op. cit., p. 104.

30- Rutschowscaya, op. cit., p. 36.

31- Dimand (1926), op. cit., p. 104. 
- Cultural Heritage of the Egyptian Form: An Approach to the Design Tradition of Hanging Textiles

32- M. S. Dimand, 'Classification of Coptic Textiles', in Coptic Egypt, T. B. M. Press, Ed., Brooklyn Institute of Arts and Sciences, New York, 1944, pp. 5158, p. 54.

33- S. J. Davis, "Fashioning a Divine Body: Coptic Christology and Ritualized Dress," The Harvard Theological Review, vol. 98, no. 3, pp. 335-362, 2005, p. 349 and 351.

34- A. Y. Kakovkin, 'Coptic Works of Art Bearing Depictions of the Rape of Europa', Ancient Civilizations from Scythia to Siberia, vol. 6, no. 3-4, 2000, pp. 297-316, p.303.

35- S. D. Nersessian, "Some aspects of Coptic painting," in Coptic Egypt, Brooklyn Institute of Arts and Sciences, New York, 1944, pp. 43-50, p. 49.

36- Cooney, op. cit., p. 38.

37- Kybalová, op. cit., p. 60-87.

38- Kakovkin, op. cit., p. 315.

39- Kybalová, op. cit., p. 41; Dimand (1944), op. cit., p. 52.

40- Kybalová, op. cit., pp. 41-42.

41- F. Spuhler, Carpets from Islamic lands, Thames and Hudson, London, 2012, p. 23.

42- J. Shapley, 'A new reading of old Egyptian textiles', The Journal of Aesthetics and Art Criticism, vol. 20, no. 4, 1962, pp. 375-388, p. 386.

43- R. Guest and A. F. Kendrick, 'The earliest dated Islamic textiles', The Burlington Magazine for Connoisseurs., vol. 60, no. 349, 1932, pp. 185-191, p. 185.

44- R. B. Serjeant, 'Material for a history of Islamic textiles up to Mongol conquest', Ars Islamica, vol. 15/16, 1951, pp. 29-85, p. 65.

45- A. E. Froom, 1400-1600: The Islamic world, in History of design: Decorative arts and material culture, 1400-2000, P. Kirkham and S. Weber, Eds., Yale University Press, New Haven and London, 2013, pp. 48-65.

46- Spuhler, op. cit., p.23.

47- Serjeant, op. cit., p. 65.

48- Shapley, op. cit., pp.385-386.

49- I. El-Said and A. Parman, Geometric Concepts in Islamic Art, World of Islam Festival Publishing Company Ltd., London, 1976.

50- O. Graber, The formation of Islamic art, Yale University Press, New Haven and London, 1987, p.125, p. 118. 
51- E. Baer, Islamic Ornament, Edinburgh University Press, Edinburgh, 1998, p. 3.

52- T. Burckhardt, Introduction to Islamic Art, in The arts of Islam: Hayward Gallery, 8 April- 4 July 1976, D. Jones and G. Michell, Eds., The Arts Council of Great Britain, London, pp. 65-118, p.34.

53- Baer, op. cit., p. 3.

54- Knotted pile is a method used in carpets, rugs and wall hangings; "Rya Knots: Fringe can be made up of rya knots, a Scandinavian word describing the traditional rugs made using the type of knot that creates a double-sided pile of yarn". see http://www.interweave.com/article/weaving/diy-wall-hanginginspiration-techniques/

55- D. King, Textiles, in The arts of Islam: Hayward Gallery, 8 April- 4 July 1976, D. Jones and G. Michell, Eds., The Arts Council of Great Britain, London, 1976, pp. 66-69.

56- O.-H. Jeong, 'An Autoethnographical Study of Culture, Power, Identity and Art Education in Post-Colonial South Korea', The International Journal of Art and Design Education, 2016, p.4.

57- D. Noyes, 'Tradition: Three Traditions', Journal of Folklore Research, vol. 46, no. 3, 2009, pp. 233-268, pp.233-248.

58- Jeong, op. cit., p. 4.

59- Micheli and Gemser, op. cit., p. 617.

60- A. Lascar, "To the Rescue of Traditions: Emotional Design and Cultural Values: A Case Study Based on Barranquilla's Carnival", Journal of Arts and Humanities, vol. 3, no. 4, 2014, pp. 77-87, p. 77.

61- A. Skjerven, 'Cultural Traditions for the Sake of Innovation: the Concept of Scandinavian Design as a Potential Tool in the Development of a Sustainable China', Sustainable Development, vol. 20, no. 3, 2012, pp. 230-238, pp. 231234.

62- Y. Yadgar, 'Tradition', Human Studies, vol. 36, no. 4, 2013, pp. 451-470, p.461.

63- Jeong, op. cit., p. 1.

64- Lascar, op. cit., p. 80-82.

65- Noyes, op. cit., p. 233-239.

66- Micheli and Gemser, op. cit., p. 617.

67- H. M. MacNeil and B. Mak, 'Constructions of Authenticity', Library Trends, vol. 56, no. 1, 2007, pp. 26-52, p.26. 
68- D. Biggs, 'Textiles in Situ: Their Find Spots in Egypt and Neighbouring Countries in the First Milennium CE by Sabine Schrenk', Journal of Near Eastern Studies, vol. 68, no. 2, 2009, pp. 152-154.

69- D. Z. Meilach, Making contemporary rugs and wall hangings, AbelardSchumann, London, 1970, p.13.

70- Stauffer, op. cit., p. 5-15.

71- R. Pippin, 'Authenticity in Painting: Remarks on Michael Fried's Art History', Critical Inquiry, vol. 31, no. 3, 2005, pp. 575-598, p. 578.

72- C. Guignon, 'Authenticity', Philosophy Compass, vol. 3, no. 2, 2008, pp. 277290, p. 277.

73- MacNeil and Mak, op. cit., p. 26 and 28.

74- J. Liedtka, 'Strategy Making and the Search for Authenticity', Journal of Business Ethics., vol. 80, no. 2, 2008, pp. 237-248, p.240.

75- G. Pollock, Does Art think? How can we think the Feminine, Aesthetically?, in Art and Thought, D. Arnold and M. Iversen, Eds., Blackwell Publishing, Malden, MA, 2003, pp. 129-155.

76- I. Buchanan, A Dictionary of Critical Theory, Oxford University Press, 2010.

77- D. C. Smith and C. R. Stannard, 'Negotiating Personal Needs and Authenticity: Exploring Design Decisions of Reenactors' Regency Gowns', Clothing and Textiles Research Journal, vol. 34, no. 4, 2016, pp. 287-302, p.290 and 296.

78- D. Chandler and R. Munday, A Dictionary of Media and Communication, 1 edn, Oxford University Press, 2010.

79- W. Blattner, 'Authenticity and Resoluteness, in The Cambridge Companion to Heidegger's Being and Time, M. A. Wrathall, Ed., Cambridge University Press, Cambridge; New York, 2013, p. 324.

80- L. Darby, Issues of Authenticity in Contemporary Design: The Smoke Series by Maarten Baas, in Art and Authenticity, M. Aldrich and J. Hackforth-Jones, Eds., Furnham, Lund Humphries in association with Sotheby's Institute of Art, 2012, p. 120.

81- J. O. Young, 'Art, Authenticity and Appropriation', Frontiers of Philosophy in China, vol. 1, no. 3, 2006, pp. 455-476, p. 466.

82- S. Jones, "Negotiating Authentic Objects and Authentic Selves", Journal of Material Culture., vol. 15, no. 2, 2010, pp. 181-203, p. 182.

83- G. Jahoda, "Critical reflections on some recent definitions of "Culture", Culture and Psychology, vol. 18, no. 3, 2012, pp. 289-303, p. 290; M. Asplet 
and M. Cooper, 'Cultural designs in New Zealand souvenir clothing: the question of authenticity', Tourism Management, vol. 21, no. 3, 2000, pp. 307312, p. 308.

84- Pippin, op. cit., p. 588.

85- Guignon, op. cit., p. 279.

86- Jones, op. cit., p. 182.

87- Guignon, op. cit., p. 282.

88- Y. Bai, J. Tan, T.-M. Choi and R. Au, 'Commercializing artistic authenticity via collaborative design', Asia Pacific Journal of Marketing and Logistics, vol. 21, no. 2, 2009, pp. 243-266, p. 243.

89- J. C. Van Camp, 'Originality in Postmodern Appropriation Art', Journal of Art Management, Law and Society, vol. 36, no. 4, 2007, pp. 247-258, p. 248-249.

90- P. Crowther, 'Creativity and Originality in Art', British Journal of Asethetics, vol. 31, no. 4, 1991, pp. 31-309, p. 303.

91- Darby, op. cit., p. 108-121.

92- B. T. Christensen and L. J. Ball, 'Dimensions of creative evaluation: Distinct design and reasoning strategies for aesthetic, functional and originality judgments, Design studies, vol. 45, no. part A, 2016, pp. 116-136, p.118.

93- MacNeil and Mak, op. cit., p. 26.

94- G. A. Fine, 'Crafting Authenticity: The Validation of Identity in Self-Taught Art', Theory and Society, vol. 32, no. 2, 2003, pp. 153-180, p. 155.

95- Ş. T. Öğ̈̈t, "Material Culture of Tea in Turkey: Transformation of Design through Tradition, Modernity and Identity," The Design Journal, vol. 12, no. 3, pp. 339-363, 2009, p. 359.

96- A. Yagou, "Metamorphoses of Formalism: National Identity as a Recurrent Theme of Design in Greece," Journal of Design History, vol. 20, no. 2, 2007, pp. 145-159, p. 156. 


\title{
التراث الثقافى لاشكل الصرى: هنهج لتقاليد التصميم فى المنسوجات المعلقة.
}

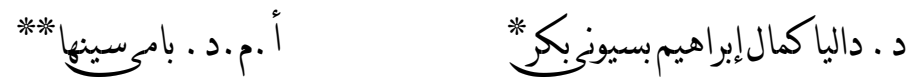 \\ الماخص العربي
}

هذا البحثث يهتمر بتطور تصميهم المنسسوجات المعلقـة فى مصدر، والهدف هـو تحلديد المعتقدات

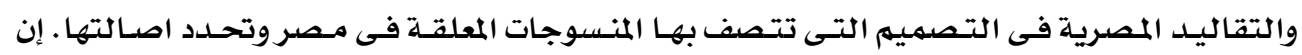

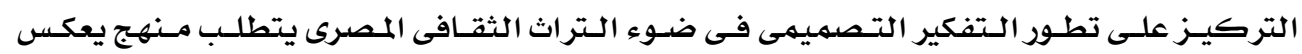

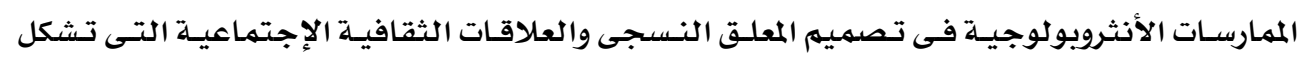
إستراتيجيات تصميم المنسوجات المعلقة فى التاريخ المصرىى.

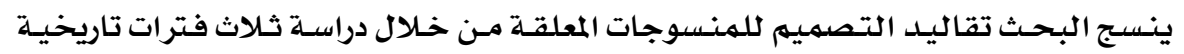

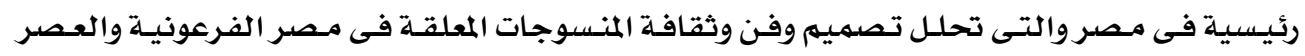

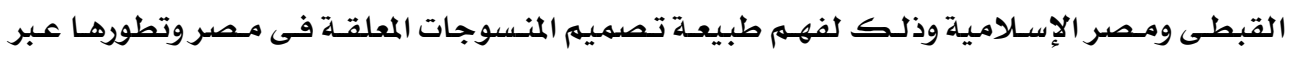
العصورومعرفة تقاليد تصميهم المعلق فى كل عصدر، إلى جانب تحليـل تأثير تكنولوجيا النسيـج على الأسـلوب القبطى . تقاليـد التصميهم عبر التاريخ المصرى تعتبر ميكانيكيـة بنائيسة تنسسج العلاقـة بـين

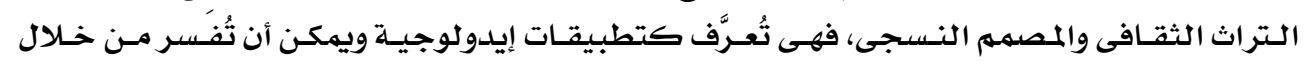

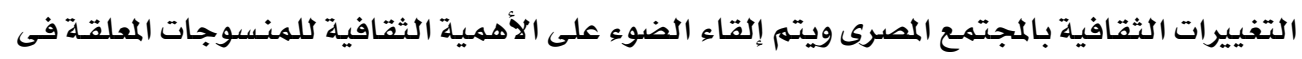

بـراسـة الثلاث عصور بالتاريخ المصرى، يتضح لنا أن تصميهم المنسوجات المعلقة فى مصر لها

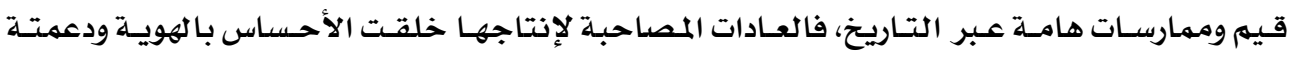
وأنشئت روابط وعلاقات بالسياق التاريخى المصرى.

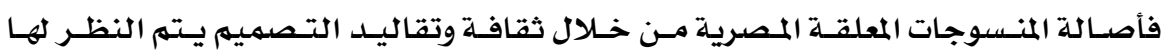

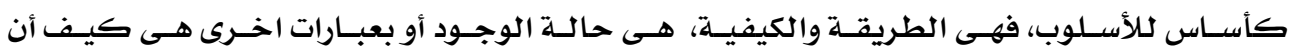

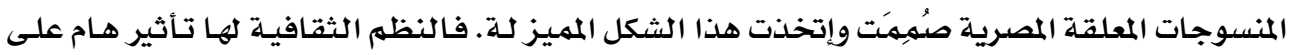

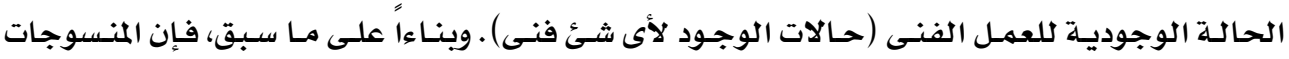

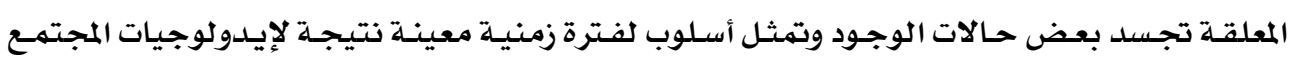
المصرى، فهى نوع من القبول للظروف الإجتماعية فى ذلك الوقت -فهى المؤيد والمدعم للة.

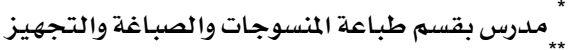

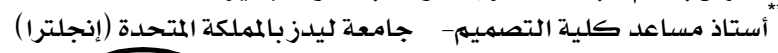

